\title{
PRECISION TOOLS FOR IRRIGATION MANAGEMENT OF TOMATO SEEDLINGS
}

\section{UTILIZAÇÃO DE FERRAMENTAS DE PRECISÃO NO MANEJO DE IRRIGAÇÃO EM MUDAS DE TOMATE}

\author{
Catariny Cabral ALEMAN; Flavio Bastos CAMPOS²; Everardo Chartuni MANTOVANI³ \\ 1. Professora Adjunta, Doutora, Departamento de Engenharia Agrícola, UFV, Viçosa, MG, Brasil. catariny@ufv.br; 2. Mestre em \\ Engenharia Agrícola, UFV, Viçosa, MG, Brasil. 3. Professor Voluntário, Doutor, Departamento de Engenharia Agrícola, UFV, Viçosa, \\ MG, Brasil.
}

\begin{abstract}
Seedling production is important to vegetable productions, however, irrigation planning for seedling production is usually inefficient due to the lack of information about water consumption by the seedlings, which decreases the quality of the seedlings. The objective of this work was to evaluate the use of hydrogel in the substrate and determine the appropriate irrigation management for the production of tomato seedlings (Solanum lycopersicom), using an automated irrigation system. The experiment was conducted in a protected environment at the Federal University of Viçosa, Brazil. Tomato seedlings were grown in polyethylene trays on substrates with, and without hydrogel. The seedlings were irrigated using an automated micro sprinkler system. Irrigation treatments were chosen considering different crop evapotranspiration (ETc) and reference evapotranspiration (ETo), and the use of timer. The height, root length, stem base diameter, root and shoot dry weights, seedlings were evaluated. The use of the hydrogel for the production of tomato seedlings resulted in seedlings with higher final heights, larger stem base diameter, greater shoot dry weight, larger crown area projection, and greater shoot relative growth rate.
\end{abstract}

KEYWORDS: Water use efficiency. Vegetables production. Water resources.

\section{INTRODUCTION}

Seedling production is an important stage, since good quality seedlings better express their genetic potential, and directly affect the plant yield. Environments used for seedling production usually shelter different crops, and water management is standardized for all crops because of the practical difficulties of applying different water regimes for each crop (REGHIN et al., 2007).

Appropriate water managements promote seedling development and water saving, since only the amount of water required by the plants is applied. The use of practices for water use efficiency through the application of appropriate irrigation depths and frequency are essential for the success of irrigated agriculture (VALNIR JÚNIOR et al., 2017).

The use of automated irrigation systems optimizes the use of water resources for agricultural production. These systems can be important tools to avoid application of excessive irrigation depths and reduce labor costs. Thus, the adoption of these techniques that use automatic control of irrigation by producers is important to improve water use efficiency (SANTOS et al., 2015). According to Lino et al. (2017), the use of resistive sensors to monitor soil moisture coupled to an Arduino platform can be efficient to determine irrigation time.

The use of hydrogels in agriculture to improve productivity rates is increasing in recent decades. Hydrogels are water-retaining polymers that can be mixed with soil or substrate to alter their physical and chemical properties, and increase water retention and nutrient absorption (FAGUNDES et al., 2015).

The use of soil conditioners can alter soil (or substrate)-water-plant-atmosphere relationships by modifying the water use of the system. This can provide greater water security to the crop, greater water use efficiency, and higher seedling quality, however, the value of these parameters, and improvements that could be reached are little studied (MARQUES; CRIPA; MARTINEZ, 2013).

Considering the need of techniques to promote water use efficiency in greenhouse nurseries, the objective of this study was to evaluate the use of hydrogel in the substrate and determine the appropriate irrigation management for the production of tomato seedlings (Solanum lycopersicom), using an automated irrigation system. 


\section{MATERIAL AND METHODS}

The experiment was conducted at the Diogo Alves de Mello Experimental Field of the Federal University of Viçosa, in Viçosa, state of Minas Gerais, Brazil. The region has a Cwa, hot temperate mesothermic climate, with rainy summer and dry winter, according to the Köppen classification (STEIDLE NETO; ZOLNIER; LOPES, 2014). Tomato (Solanum lycopersicom) plants of the cultivar Santa Cruz Kada (Paulista) were grown from September 4 to September 29, 2017. Seeding was carried out in 128-cell polyethylene trays, at $1.25 \mathrm{~m}$ above the ground. The trays were filled with a commercial substrate (Carolina Padrão) (Table 1).

The water retained in the substrate (WRS) was quantified in laboratory. Five trays were filled with the substrate in its original condition of moisture. The trays were weighed in a scale (model Mark K12; TECNAL, SP, Brazil) with precision of
$0.1 \mathrm{~g}$. Then, they were saturated with water at room temperature up to the time the trays stopped draining, and the trays were weighed again. The water retained in the substrate (WRS; $\mathrm{mm}$ ) was calculated according to Equation 01,

$W R S=\frac{1}{A_{b}} \cdot \frac{1}{d_{a}} \cdot \sum_{i=1}^{j} \frac{4 m_{i}}{i}$ 1

wherein $A_{b}$ is the area of a tray $\left(0.1352 \mathrm{~m}^{2}\right) ; d_{a}$ is the water density $\left(1000 \mathrm{~g} \mathrm{dm}^{-3}\right) ; j$ is the number of weighed trays (5); and $\Delta m_{i}$ is the weight (g) of water retained in each sampled tray.

The WRS for seedling production is defined as the point between field capacity and dried substrate. A different reference was adopted in the present work, considering the point between field capacity and original conditions of the substrate. Thus, the mean water depth applied to the substrate was $4.40 \mathrm{~mm}$.

Table 1. Chemical analyze of the Carolina Padrão substrate.

\begin{tabular}{|c|c|c|c|c|c|}
\hline \multirow{2}{*}{$\mathrm{pH}\left(\mathrm{H}_{2} \mathrm{O}\right)$} & $P$ & $\mathrm{~K}$ & $\mathrm{Ca}^{+2}$ & $\mathrm{Mg}^{+2}$ & $\mathrm{Al}^{+3}$ \\
\hline & $\mathrm{mg} / \mathrm{dm}^{3}$ & & & $\mathrm{cmol}_{\mathrm{c}} / \mathrm{dm}^{3}$ & \\
\hline 6.4 & 26.1 & 152 & 7.5 & 13.4 & 0.0 \\
\hline $\mathrm{H}+\mathrm{Al}$ & SB & $\mathrm{CTC}(\mathrm{t})$ & CTC(T) & $\mathrm{V} \%$ & $\mathrm{~m} \%$ \\
\hline
\end{tabular}

$\begin{array}{lrrrrr}4.0 & 21.3 & 21.3 & 25.3 & 84 & 0\end{array}$

$\mathrm{pH}$ in water, and $\mathrm{KCl}$ and $\mathrm{CaCl}^{2}$ at 1:2.5 ratio; $\mathrm{P}$, and $\mathrm{K}$ extracted by Mehlich-1; $\mathrm{Ca}, \mathrm{Mg}, \mathrm{Al}^{-}$extracted by $\mathrm{KCl} 1 \mathrm{~mol} \mathrm{~L}-1$; $+\mathrm{Al}$ extractor by calcium acetate $0.5 \mathrm{~mol} \mathrm{~L}^{-1}$ at $\mathrm{pH} 7.0 ; \mathrm{SB}=$ sum of exchangeable bases; CTC $(\mathrm{t})=$ effective cation exchange capacity; CTC $(\mathrm{T})=$ cation exchange capacity at $\mathrm{pH} 7.0 ; \mathrm{V} \%=$ saturation by bases; $\mathrm{m} \%=$ saturation by aluminum.

The rate of the hydrogel used in the experiment (Hydroplan EB, Hydroplan, São Paulo, Brazil) was 5.3 grams of hydrogel per liter of substrate (SANTOS et al., 2015).

A microsprinkler irrigation system was used in the experiment; it was evaluated according to its working conditions using the Christiansen uniformity coefficient (CUC; \%), according to Equation 02,

$$
C U C=100\left(1-\frac{\sum_{i=1}^{2}\left|q_{i}-q_{i n}\right|}{n q_{m}}\right)
$$

wherein $q_{i}$ is the flow rate in the collector $\left(\mathrm{L} \mathrm{h}^{-1}\right) ; n$ is the number of collectors; $q_{m}$ is the mean flow rate of $n$ collectors $\left(\mathrm{L} \mathrm{h}^{-1}\right)$.

A system of acquisition and processing of meteorological data, and a control of the experimental irrigation, consisting of a microcontroller (ATMega 2560, Atmel, San Jose, USA) developed in an Arduino ATMega board, a real time clock, a memory card module, an air temperature sensor, and a relative humidity and global radiation sensor (pyranometer), were used to more efficiently determining the irrigation depth to be used.

An accumulated water depth (IRN) (Eq. 03 and Eq. 04) corresponding to the crop evapotranspiration (ETc) between two consecutive irrigations was considered for the irrigation management. The drain was considered null in the model assuming that the irrigations were carried out with application intensity (IA) below the water infiltration rate into the substrate (BERNARDO et al., 2019).

$$
\begin{aligned}
& I R N_{a C}=E T_{\sigma_{a C}}+\text { drain }+ \text { flow }+ \text { rain } \\
& I R N_{a c}=E T_{Q \varepsilon E}
\end{aligned}
$$

The microcontroller evaluated the average hourly air temperature $\left(\mathrm{T}_{\mathrm{ar}}\right)$, relative humidity $\left(\mathrm{U}_{\mathrm{ar}}\right)$, global radiation $\left(\mathrm{R}_{\mathrm{g}}\right)$, and $\mathrm{ET}_{\mathrm{o}}$. Then, the hourly $\mathrm{ET}_{\mathrm{c}}$ and the accumulated depth $\left(\operatorname{IRN}_{a c}\right)$ were calculated for each treatment. The ETc was determined using the crop coefficient for the experimental conditions, 
according to Campos (2017). The Kc used for the substrates were 1.55 (with hydrogel), and 1.39 (without hydrogel). The treatments used are shown in Table 2.

Table 2. Experimental treatments for tomato seedling production.

\begin{tabular}{llllll}
\hline Treatment & Hydrogel & Timer & $E T_{Q}$ & $K_{q}$ & DMP \\
\hline T1 & Presence & Yes & - & - & - \\
T2 & Absent & Yes & - & - & - \\
T3 & Presence & - & - & 1.55 & 1.00 \\
T4 & Absent & - & - & 1.39 & 1.00 \\
T5 & Presence & - & $50 \%$ & - & 1.00 \\
T6 & Absent & - & $50 \%$ & - & 1.00 \\
T7 & Presence & - & $100 \%$ & - & 1.00 \\
T8 & Absent & - & $100 \%$ & - & 1.00 \\
\hline
\end{tabular}

*DMP is maximum allowed deficit.

Plant height, root length, and root and shoot dry weights were evaluated in six evaluations during the development of the seedlings. Stem base diameter was evaluated in a split-plots arrangement at 25 days after emergence (DAE).

A complete randomized experimental design was used, in a $4 \times 2$ factorial arrangement, consisting of four irrigation managements and two substrates. The means were compered using the Tukey's test at 5\% significance level.

\section{RESULTS AND DISCUSSION}
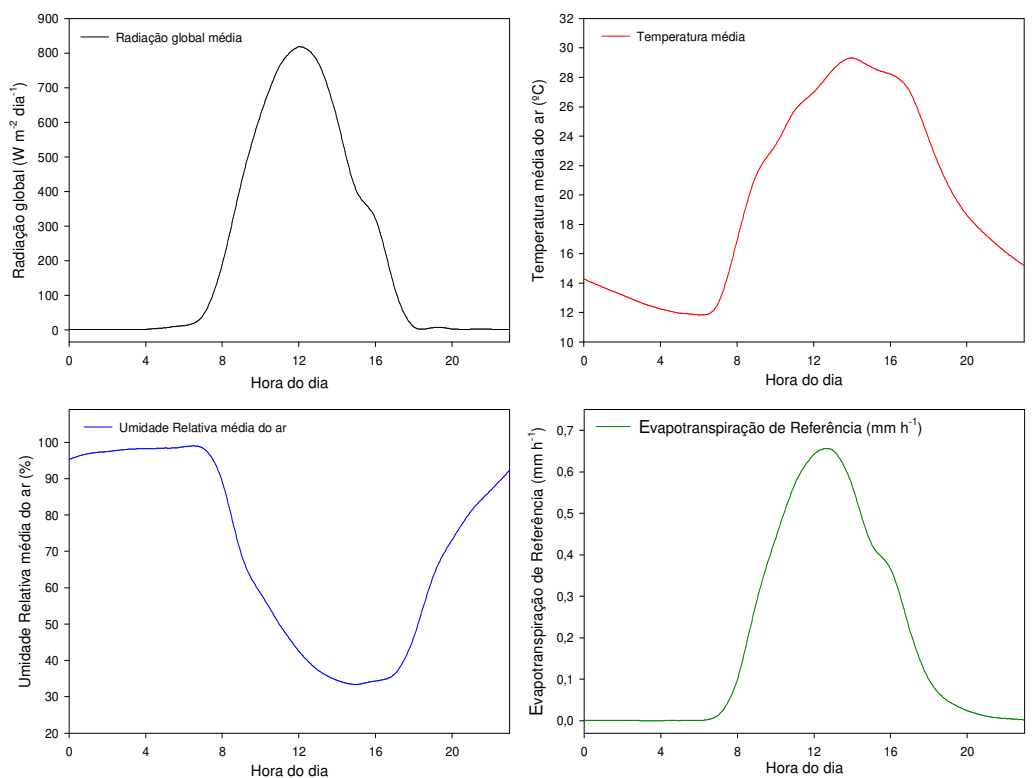

Figure 1. Microclimate variables (mean hourly global radiation, mean air temperature, mean relative air humidity, and reference evapotranspiration) during the tomato seedling production cycle.

The water was balanced in real time during the experiment, considering the interactions within every 60 minutes. Figure 2 shows the balance adopted for the timer (with, and without hydrogel),
The means of the microclimate variables of the study region (Figure 1) were as expected (ALLEN et al., 1998), with maximum global radiation near the noon, showing sunny days; average hourly air temperatures lower at night, and higher (above $20^{\circ} \mathrm{C}$ ) between 9:00 a.m. and 7:00 p.m.; maximum mean air relative humidity between $0 \mathrm{~h}$ and $8 \mathrm{~h}$, decreasing with increasing global radiation, reaching the minimum $(35 \%)$ around $4 \mathrm{~h}$. The average reference evapotranspiration calculated with these variables presented a profile similar to the global radiation, with a maximum of approximately $0.65 \mathrm{~mm} \mathrm{~h}^{-1}$ at $12 \mathrm{~h}$. 
Figure 2 and Table 3 shows the hourly ETo, hourly ETc, accumulated water depth $\left(\mathrm{IRN}_{\mathrm{ac}}\right)$, and applied water depth $\left(\mathrm{IR}_{\mathrm{apl}}\right)$, and the frequency and number of irrigations of each treatment.

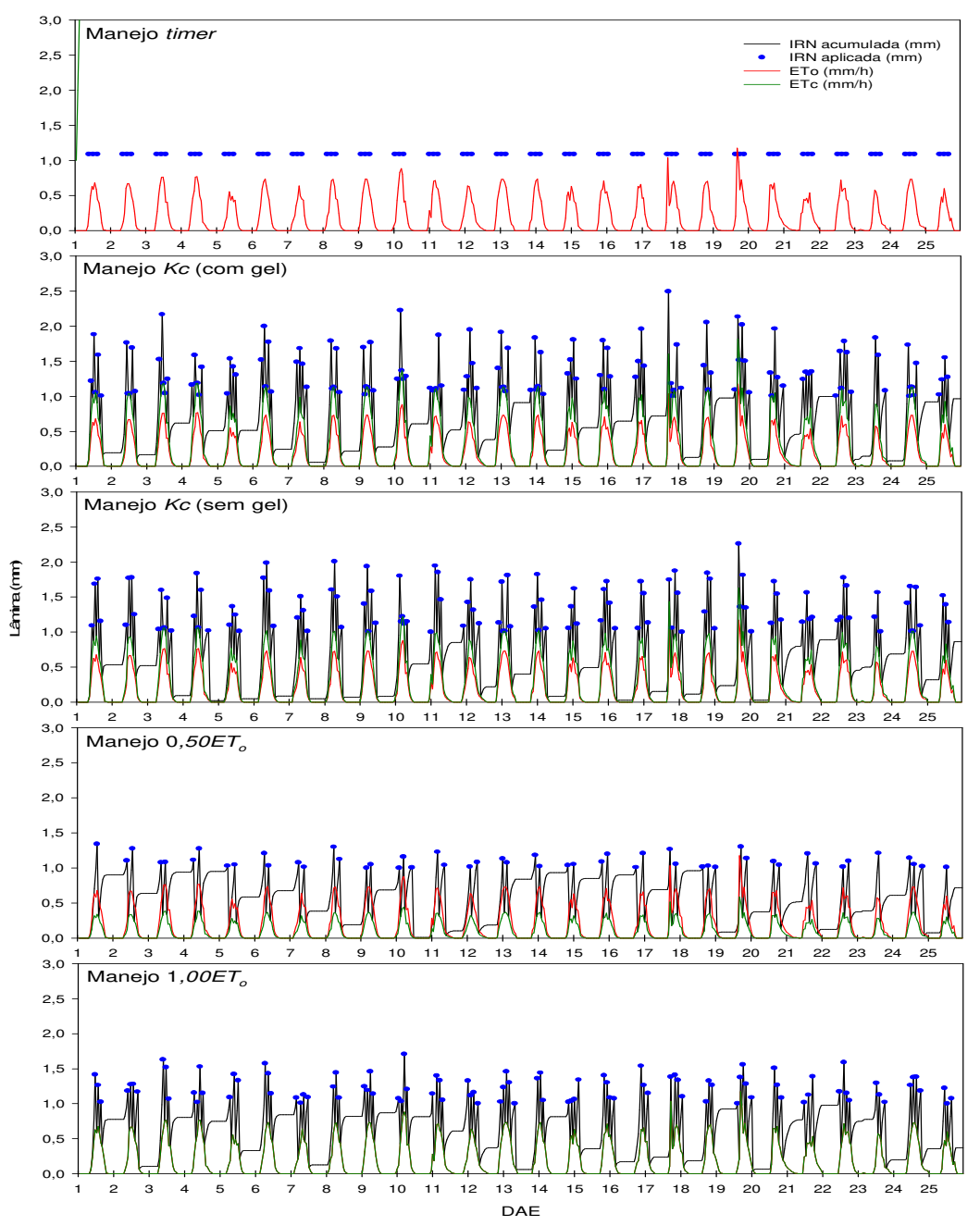

Figure 2. Water balance performed using a microcontroller for timer (with and without gel), Kc of 1.55 (with gel), Kc of 1.39 (without gel), $0.50 \%$ ETo (with and without gel), and $1.00 \%$ of ETo (with and without gel), during a 25-day cycle.

Table 3. Average number of irrigations $\left(\mathrm{N}_{\mathrm{irr}}\right)$, average irrigation time $\left(\mathrm{T}_{\text {irr }}\right)$, and total water depth applied $\left(\mathrm{L}_{\mathrm{irr}}\right)$.

\begin{tabular}{|c|c|c|c|c|}
\hline \multicolumn{2}{|c|}{ Treatment } & \multirow{2}{*}{$\begin{array}{l}\overline{\mathrm{N}}_{\mathrm{irr}} \\
78\end{array}$} & \multirow{2}{*}{$\begin{array}{l}\overline{\mathrm{T}}_{\mathrm{irr}}(\mathrm{min}) \\
2.0\end{array}$} & \multirow{2}{*}{$\begin{array}{l}\mathrm{L}_{\mathrm{irr}}(\mathrm{mm}) \\
84.8\end{array}$} \\
\hline Timer & - with gel & & & \\
\hline Timer & - without gel & 78 & 2.0 & 84.8 \\
\hline \multicolumn{2}{|c|}{$\mathbb{R}_{g}-$ with gel } & 130 & 2.5 & 176.7 \\
\hline \multicolumn{2}{|c|}{$\mathrm{k}_{c}-$ without gel } & 117 & 2.5 & 159.0 \\
\hline $0.50 \mathrm{ET}_{0}$ & - with gel & 52 & 1.8 & 56.6 \\
\hline $0.50 \mathrm{ET}_{8}$ & - without gel & 52 & 1.8 & 56.6 \\
\hline $1.00 \mathrm{ET}_{8}$ & - with gel & 94 & 2.0 & 113.6 \\
\hline $1.00 \mathrm{ET}_{8}$ & - without gel & 94 & 2.0 & 113.6 \\
\hline
\end{tabular}

The interaction between the factors DAE, management, and substrate was significant for plant height (Table 4). Regarding the seedlings produced without hydrogel, no significant difference in plant height between the 4 managements was found up to the $22 \mathrm{DAE}$; in the final evaluation (25 DAE), the management 0.50ETo resulted in higher plant heights when compared to the treatments with timer, and $\mathrm{Kc}$ managements. The treatment with 1.00ETo remained with intermediate plant heights. 
Table 4. Plant height $(\mathrm{cm})$ of tomato seedlings produced with, and without hydrogel in the substrate, and subjected to different irrigation managements.

\begin{tabular}{|c|c|c|c|c|c|c|}
\hline \multirow[b]{2}{*}{ Management } & \multicolumn{2}{|l|}{$9 \mathrm{DAE}$} & \multicolumn{2}{|l|}{$11 \mathrm{DAE}$} & \multicolumn{2}{|l|}{$15 \mathrm{DAE}$} \\
\hline & $\begin{array}{l}\text { With } \\
\text { hydrogel }\end{array}$ & $\begin{array}{l}\text { Without } \\
\text { hydrogel }\end{array}$ & $\begin{array}{l}\text { With } \\
\text { hydrogel }\end{array}$ & $\begin{array}{l}\text { Without } \\
\text { hydrogel }\end{array}$ & $\begin{array}{l}\text { With } \\
\text { hydrogel }\end{array}$ & $\begin{array}{l}\text { Without } \\
\text { hydrogel }\end{array}$ \\
\hline Timer & $3.85 \mathrm{Aa}$ & $3.15 \mathrm{Aa}$ & $4.07 \mathrm{Aa}$ & $2.81 \mathrm{Ab}$ & $6.87 \mathrm{ABa}$ & $4.96 \mathrm{Ab}$ \\
\hline $\mathrm{Kc}$ & $3.37 \mathrm{Aa}$ & $3.17 \mathrm{Aa}$ & $3.55 \mathrm{Aa}$ & $3.06 \mathrm{Aa}$ & $5.52 \mathrm{Ba}$ & $4.82 \mathrm{Aa}$ \\
\hline 0.50 ETo & 4.01 Aa & $4.01 \mathrm{Aa}$ & $3.40 \mathrm{Aa}$ & $3.36 \mathrm{Aa}$ & $7.25 \mathrm{Aa}$ & $4.42 \mathrm{Ab}$ \\
\hline 1.00 ETo & $3.12 \mathrm{Aa}$ & $3.12 \mathrm{Aa}$ & $3.86 \mathrm{Aa}$ & $3.31 \mathrm{Aa}$ & $6.71 \mathrm{ABa}$ & $4.41 \mathrm{Ab}$ \\
\hline \multirow[b]{2}{*}{ Management } & $18 \mathrm{DAE}$ & & 22 DAE & & $25 \mathrm{DAE}$ & \\
\hline & $\begin{array}{l}\text { With } \\
\text { hydrogel }\end{array}$ & $\begin{array}{l}\text { Without } \\
\text { hydrogel }\end{array}$ & $\begin{array}{l}\text { With } \\
\text { hydrogel }\end{array}$ & $\begin{array}{l}\text { Without } \\
\text { hydrogel }\end{array}$ & $\begin{array}{l}\text { With } \\
\text { hydrogel }\end{array}$ & $\begin{array}{l}\text { Without } \\
\text { hydrogel }\end{array}$ \\
\hline Timer & $9.87 \mathrm{Aa}$ & $4.90 \mathrm{Ab}$ & $12.88 \mathrm{Aa}$ & $5.85 \mathrm{Ab}$ & $15.15 \mathrm{Aa}$ & $6.46 \mathrm{Bb}$ \\
\hline $\mathrm{Kc}$ & $7.35 \mathrm{Ca}$ & $5.25 \mathrm{Ab}$ & $10.36 \mathrm{Ba}$ & $6.46 \mathrm{Ab}$ & $12.42 \mathrm{Ba}$ & $5.80 \mathrm{Bb}$ \\
\hline 0.50 ЕТо & $9.01 \mathrm{ABa}$ & $5.38 \mathrm{Ab}$ & $12.45 \mathrm{Aa}$ & $6.76 \mathrm{Ab}$ & $12.56 \mathrm{Ba}$ & $7.98 \mathrm{Ab}$ \\
\hline 1.00 ETo & $8.16 \mathrm{BCa}$ & $5.21 \mathrm{Ab}$ & $11.80 \mathrm{Aa}$ & $5.97 \mathrm{Ab}$ & $13.00 \mathrm{Ba}$ & $6.76 \mathrm{ABb}$ \\
\hline
\end{tabular}

Means followed by the same uppercase letters in the columns, or lowercase letters in the rows do not differ by the Tukey test at the $5 \%$ probability level.

The height of seedlings is a important parameter for analyse the quality of seedlings. However, this parameter is important to predict seedling uniformity and estimate their development in the field (TITTONELL; GRAZIA; CHIESA, 2002).

Different heights of seedlings were found at 11 DAE with the use of hydrogel, and at 22 DAE without hydrogel. The use of hydrogel affected the seedling precocity. Similar result was found during the vegetative development of sweet pepper plants with the use of hydrogel (TITTONELL; GRAZIA; CHIESA, 2002).
Navroski et al. (2016), and Bernardi et al. (2012) evaluated the use of hydrogel $\left(6 \mathrm{~g} \mathrm{~L}^{-1}\right)$ for the production of eucalyptus seedlings and found that the use of hydrogel favored the development of the seedlings, reducing the requirement of nutritional supplementation in about $20 \%$.

The interaction between the factors DAE, management, and substrate was not significant for root length (Table 5), but there were significant interactions between the factors DAE and substrate, and DAE and management for this variable.

Table 5. Root length $(\mathrm{cm})$ of tomato seedlings produced with, and without hydrogel in the substrate, and subjected to different irrigation managements.

\begin{tabular}{|c|c|c|c|c|c|c|}
\hline \multirow[b]{2}{*}{ Management } & \multicolumn{2}{|l|}{ 9 DAE } & \multicolumn{2}{|l|}{$11 \mathrm{DAE}$} & \multicolumn{2}{|l|}{$15 \mathrm{DAE}$} \\
\hline & $\begin{array}{l}\text { With } \\
\text { hydrogel }\end{array}$ & $\begin{array}{l}\text { Without } \\
\text { hydrogel }\end{array}$ & $\begin{array}{l}\text { With } \\
\text { hydrogel }\end{array}$ & $\begin{array}{l}\text { Without } \\
\text { hydrogel }\end{array}$ & $\begin{array}{l}\text { With } \\
\text { hydrogel }\end{array}$ & $\begin{array}{l}\text { Without } \\
\text { hydrogel }\end{array}$ \\
\hline Timer & $5.41 \mathrm{Bb}$ & $8.12 \mathrm{Aa}$ & $8.33 \mathrm{Aa}$ & $9.25 \mathrm{Aa}$ & $9.83 \mathrm{Aa}$ & $9.98 \mathrm{Aa}$ \\
\hline $\mathrm{Kc}$ & $6.63 \mathrm{ABa}$ & $8.93 \mathrm{Aa}$ & $8.13 \mathrm{Aa}$ & $10.02 \mathrm{Aa}$ & $9.30 \mathrm{Aa}$ & $9.68 \mathrm{Aa}$ \\
\hline 0.50 ЕТо & 7.01 ABa & 7.12 Aa & $7.90 \mathrm{Aa}$ & $9.67 \mathrm{Aa}$ & $9.77 \mathrm{Aa}$ & $10.38 \mathrm{Aa}$ \\
\hline $1.00 \mathrm{ETo}$ & $9.78 \mathrm{Aa}$ & $9.10 \mathrm{Aa}$ & $8.41 \mathrm{Aa}$ & $10.67 \mathrm{Aa}$ & $9.73 \mathrm{Aa}$ & $11.10 \mathrm{Aa}$ \\
\hline \multirow[b]{2}{*}{ Management } & $18 \mathrm{DAE}$ & & $22 \mathrm{DAE}$ & & $25 \mathrm{DAE}$ & \\
\hline & $\begin{array}{l}\text { With } \\
\text { hydrogel }\end{array}$ & $\begin{array}{l}\text { Without } \\
\text { hydrogel }\end{array}$ & $\begin{array}{l}\text { With } \\
\text { hydrogel }\end{array}$ & $\begin{array}{l}\text { Without } \\
\text { hydrogel }\end{array}$ & $\begin{array}{l}\text { With } \\
\text { hydrogel }\end{array}$ & $\begin{array}{l}\text { Without } \\
\text { hydrogel }\end{array}$ \\
\hline Timer & $11.73 \mathrm{Aa}$ & $11.17 \mathrm{Aa}$ & $13.53 \mathrm{Aa}$ & $11.53 \mathrm{Aa}$ & $15.00 \mathrm{Aa}$ & $14.23 \mathrm{Aa}$ \\
\hline $\mathrm{Kc}$ & $11.12 \mathrm{Aa}$ & $10.96 \mathrm{Aa}$ & $12.40 \mathrm{Aa}$ & $12.63 \mathrm{Aa}$ & $11.97 \mathrm{ABa}$ & $12.33 \mathrm{Aa}$ \\
\hline 0.50 ETo & $11.58 \mathrm{Aa}$ & $10.38 \mathrm{Aa}$ & $11.40 \mathrm{Aa}$ & $10.33 \mathrm{Aa}$ & $10.73 \mathrm{Bb}$ & $13.76 \mathrm{Aa}$ \\
\hline 1.00 ETo & $12.10 \mathrm{Aa}$ & $11.02 \mathrm{Aa}$ & $13.16 \mathrm{Aa}$ & $10.21 \mathrm{Ab}$ & $12.81 \mathrm{ABa}$ & $11.85 \mathrm{Aa}$ \\
\hline
\end{tabular}

Means followed by the same uppercase letters in the columns, or lowercase letters in the rows do not differ by the Tukey test at the 5\% probability level.

There was a limitation in root development in depth, because the seedlings reached the lower part of the tray cell, and the roots had reduced contact zone with the substrate, hindering root aeration, and water availability (WALTHIER et al., 2016). 
The insufficient conditions for root development generated dense and shallow root systems, and caused the death of the meristem root. Therefore, secondary root development occurred rather than deep development.

No significant differences in root length during the cycle for the managements and treatments with, and without hydrogel were expected. Seedlings treated with hydrogel had different root lengths at the beginning (9 DAE) and end (25 DAE) of the cycle. At $9 \mathrm{DAE}$, the difference was probably due to the uneven germination over the first 5 days, which included the interval between sowing and emergence. At 25 DAE, the difference found was between the irrigation managements; the treatments with timer presented an higher mean than that with 0.50ETo.The stem base diameter (SBD) was measured only at the $25 \mathrm{DAE}$, which corresponds to the last day of the molting cycle (Table 6).

Table 6. Stem base diameter of tomato seedlings produced with, and without hydrogel in the substrate, and subjected to different irrigation managements.

\begin{tabular}{lll}
\hline & With hydrogel & Without hydrogel \\
\hline Timer & $2.74 \mathrm{Aa}$ & $1.79 \mathrm{Ab}$ \\
Kc & $2.64 \mathrm{Aa}$ & $1.65 \mathrm{Ab}$ \\
0.50 ETo & $2.30 \mathrm{Ba}$ & $1.92 \mathrm{Ab}$ \\
$1.00 \mathrm{ETo}$ & $2.78 \mathrm{Aa}$ & $1.70 \mathrm{Ab}$ \\
\hline
\end{tabular}

Means followed by the same uppercase letters in the columns, or lowercase letters in the rows do not differ by the Tukey test at the 5\% probability level.

The SBD of seedlings grow in the substrate with hydrogel were lower for the timer, $\mathrm{Kc}$, and 1,00ETo treatments when compared to the 0.50ETo; and without hydrogel, no difference SBD was found when comparing the 4 managements.

Although studies show no consensus about the directly effect of SBD on seedling quality, some studies correlate SBD with tomato productivity (HERNÁNDEZ et al., 2017), and others associate SBD with other variables that result in good quality seedlings (COSTA et al., 2012).

The use of substrate with hydrogel resulted in seedlings with greater SBD in all managements. This result indicate that the irrigation depth applied to the substrate with hydrogel was readily available to the seedlings. Navroski et al. (2016) found larger SBD when using gel on the substrate or soil, and explained this result by the improved water retention and use by plants.

The root dry weight of the seedling with hydrogel was higher than that of those without hydrogel in the substrate at $15 \mathrm{DAE}$, in all irrigation managements (Table 7). This result indicates more root development in the substrate with hydrogelnot associated to their growth in depth, which was limited due to the tray cell area, but to the development of secondary roots. Navroski et al. (2016) associated the development of these roots with the effect of the use of hydrogel.

Table 7. Root dry weight $\left(10^{-4} \mathrm{~g}\right)$ of tomato seedlings produced with, and without hydrogel in the substrate, and subjected to different irrigation managements.

\begin{tabular}{|c|c|c|c|c|c|c|}
\hline \multirow[b]{2}{*}{ Management } & \multicolumn{2}{|l|}{$9 \mathrm{DAE}$} & \multicolumn{2}{|l|}{$11 \mathrm{DAE}$} & \multicolumn{2}{|l|}{$15 \mathrm{DAE}$} \\
\hline & $\begin{array}{l}\text { With } \\
\text { hydrogel }\end{array}$ & $\begin{array}{l}\text { Without } \\
\text { hydrogel }\end{array}$ & $\begin{array}{l}\text { With } \\
\text { hydrogel }\end{array}$ & $\begin{array}{l}\text { Without } \\
\text { hydrogel }\end{array}$ & $\begin{array}{l}\text { With } \\
\text { hydrogel }\end{array}$ & $\begin{array}{l}\text { Without } \\
\text { hydrogel }\end{array}$ \\
\hline Timer & $20 \mathrm{Aa}$ & $40 \mathrm{Aa}$ & $41 \mathrm{Aa}$ & $42 \mathrm{Aa}$ & $123 \mathrm{Aa}$ & $46 \mathrm{Ab}$ \\
\hline Kc & $33 \mathrm{Aa}$ & $39 \mathrm{Aa}$ & $56 \mathrm{Aa}$ & $44 \mathrm{Aa}$ & $72 \mathrm{Aa}$ & $53 \mathrm{Aa}$ \\
\hline 0.50 ETo & $26 \mathrm{Aa}$ & $27 \mathrm{Aa}$ & $40 \mathrm{Aa}$ & $43 \mathrm{Aa}$ & $104 \mathrm{Aa}$ & $49 \mathrm{Aa}$ \\
\hline 1.00 ETo & $34 \mathrm{Aa}$ & $31 \mathrm{Aa}$ & $50 \mathrm{Aa}$ & $46 \mathrm{Aa}$ & $91 \mathrm{Aa}$ & $59 \mathrm{Aa}$ \\
\hline \multirow[b]{2}{*}{ Management } & \multicolumn{2}{|l|}{$18 \mathrm{DAE}$} & \multicolumn{2}{|l|}{$22 \mathrm{DAE}$} & \multicolumn{2}{|l|}{$25 \mathrm{DAE}$} \\
\hline & $\begin{array}{l}\text { With } \\
\text { hydrogel }\end{array}$ & $\begin{array}{l}\text { Without } \\
\text { hydrogel }\end{array}$ & $\begin{array}{l}\text { With } \\
\text { hydrogel }\end{array}$ & $\begin{array}{l}\text { Without } \\
\text { hydrogel }\end{array}$ & $\begin{array}{l}\text { With } \\
\text { hydrogel }\end{array}$ & $\begin{array}{l}\text { Without } \\
\text { hydrogel }\end{array}$ \\
\hline Timer & $236 \mathrm{Aa}$ & $78 \mathrm{Ab}$ & $320 \mathrm{Aa}$ & $116 \mathrm{Ab}$ & $403 \mathrm{Aba}$ & $170 \mathrm{Ab}$ \\
\hline Kc & $207 \mathrm{Aa}$ & $108 \mathrm{Ab}$ & $268 \mathrm{Aa}$ & $173 \mathrm{Ab}$ & $323 \mathrm{Ba}$ & $168 \mathrm{Ab}$ \\
\hline 0.50 ETo & $211 \mathrm{Aa}$ & $76 \mathrm{Ab}$ & $285 \mathrm{Aa}$ & $170 \mathrm{Ab}$ & 344 Aba & $225 \mathrm{Ab}$ \\
\hline 1.00 ETo & $205 \mathrm{Aa}$ & $94 \mathrm{Ab}$ & $298 \mathrm{Aa}$ & $141 \mathrm{Ab}$ & $411 \mathrm{Aa}$ & $167 \mathrm{Ab}$ \\
\hline
\end{tabular}

Means followed by the same uppercase letters in the columns, or lowercase letters in the rows do not differ by the Tukey test at the $5 \%$ probability level. 
Secondary roots are associated with water absorption, thus, seedlings with high numbers of these roots tend to have better resistance to water deficit. This is desirable when transferring the seedling to the field. Walthier et al. (2016) found that low water availability and aeration space may be factors that affect negatively root dry weight.

The shoot dry weight of the seedlings (Table 8) at 25 DAE was significantly lower in the $0.50 \mathrm{ET}$ o when compared to the $\mathrm{Kc}$, and 1.00ETo managements. The probable increased water and nutrient retention on the substrate promoted by the hydrogel (FAGUNDES et al., 2015) reduced the water deficit effects of the different irrigation management.

Water deficit and nutritional deficiency affected seedlings in treatments with hydrogel only in the last evaluation (25 DAE), denoted by of their shoot dry weight, and slight purple coloration of the seedlings, typical of phosphorus deficiency.

Table 8. Shoot dry weight (MDAP) $\left(10^{-4} \mathrm{~g}\right)$ of tomato seedlings produced with, and without hydrogel in the substrate, and subjected to different irrigation managements.

\begin{tabular}{|c|c|c|c|c|c|c|}
\hline \multirow[b]{2}{*}{ Management } & \multicolumn{2}{|l|}{$9 \mathrm{DAE}$} & \multicolumn{2}{|l|}{$11 \mathrm{DAE}$} & \multicolumn{2}{|l|}{$15 \mathrm{DAE}$} \\
\hline & $\begin{array}{l}\text { With } \\
\text { hydrogel }\end{array}$ & $\begin{array}{l}\text { Without } \\
\text { hydrogel }\end{array}$ & $\begin{array}{l}\text { With } \\
\text { hydrogel }\end{array}$ & $\begin{array}{l}\text { Without } \\
\text { hydrogel }\end{array}$ & $\begin{array}{l}\text { With } \\
\text { hydrogel }\end{array}$ & $\begin{array}{l}\text { Without } \\
\text { hydrogel }\end{array}$ \\
\hline Timer & $174 \mathrm{Aa}$ & $94 \mathrm{Aa}$ & $228 \mathrm{Aa}$ & $92 \mathrm{Aa}$ & $641 \mathrm{Aa}$ & $128 \mathrm{Ab}$ \\
\hline $\mathrm{Kc}$ & $176 \mathrm{Aa}$ & $95 \mathrm{Aa}$ & $261 \mathrm{Aa}$ & $114 \mathrm{Aa}$ & $353 \mathrm{Aa}$ & $179 \mathrm{Aa}$ \\
\hline 0.50 ETo & $143 \mathrm{Aa}$ & $136 \mathrm{Aa}$ & $180 \mathrm{Aa}$ & $107 \mathrm{Aa}$ & $429 \mathrm{Aa}$ & $133 \mathrm{Ab}$ \\
\hline 1.00 ETo & $84 \mathrm{Aa}$ & $78 \mathrm{Aa}$ & $247 \mathrm{Aa}$ & $99 \mathrm{Aa}$ & $440 \mathrm{Aa}$ & $157 \mathrm{Aa}$ \\
\hline \multirow[b]{2}{*}{ Management } & \multicolumn{2}{|l|}{$18 \mathrm{DAE}$} & \multicolumn{2}{|l|}{$22 \mathrm{DAE}$} & \multicolumn{2}{|l|}{$25 \mathrm{DAE}$} \\
\hline & $\begin{array}{l}\text { With } \\
\text { hydrogel }\end{array}$ & $\begin{array}{l}\text { Without } \\
\text { hydrogel }\end{array}$ & $\begin{array}{l}\text { With } \\
\text { hydrogel }\end{array}$ & $\begin{array}{l}\text { Without } \\
\text { hydrogel }\end{array}$ & $\begin{array}{l}\text { With } \\
\text { hydrogel }\end{array}$ & $\begin{array}{l}\text { Without } \\
\text { hydrogel }\end{array}$ \\
\hline Timer & $1103 \mathrm{Aa}$ & $240 \mathrm{Ab}$ & $1639 \mathrm{Aa}$ & $393 \mathrm{Ab}$ & $1829 \mathrm{ABa}$ & $559 \mathrm{Ab}$ \\
\hline $\mathrm{Kc}$ & $757 \mathrm{Aa}$ & $313 \mathrm{Ab}$ & $1415 \mathrm{Aa}$ & $522 \mathrm{Ab}$ & $1916 \mathrm{Aa}$ & $533 \mathrm{Ab}$ \\
\hline 0.50 ETo & $863 \mathrm{Aa}$ & $255 \mathrm{Ab}$ & $1386 \mathrm{Aa}$ & $522 \mathrm{Ab}$ & $1495 \mathrm{Ba}$ & $774 \mathrm{Ab}$ \\
\hline 1.00 ETo & $801 \mathrm{Aa}$ & $272 \mathrm{Ab}$ & $1640 \mathrm{Aa}$ & $426 \mathrm{Ab}$ & $1999 \mathrm{Aa}$ & $667 \mathrm{Ab}$ \\
\hline
\end{tabular}

Means followed by the same uppercase letters in the columns, or lowercase letters in the rows do not differ by the Tukey test at the 5\% probability level.

\section{CONCLUSIONS}

The use of hydrogel in the substrate is an essential factor to make early morphological evaluations in tomato seedlings.
The use of substrates with hydrogel, and automate irrigation system make possible to transplant the tomato seedlings at 25 days after emergence.

RESUMO: A produção de mudas é um ponto crítico do sistema de produção de hortaliças. Devido a informações sobre o consumo de água pelas mudas, o planejamento da irrigação se torna ineficiente, fato que provoca perdas na qualidade das mudas. O objetivo do experimento foi testar o uso de hidrogel no substrato e determinar o manejo de irrigação adequado através de ferramentas de automatização do sistema de irrigação. $\mathrm{O}$ experimento foi conduzido em ambiente protegido na Universidade Federal de Viçosa. Foram produzidas mudas de tomate (Solanum lycopersicom) em bandejas de polietileno, preenchidas com substrato com e sem a presença de hidrogel. As mudas foram irrigadas com sistema de microaspersão, acionado a partir de um sistema automatizado. Os tratamentos de manejo de irrigação foram através da evapotranspiração da cultura (ETc), timer, 0.50 ETo e 1,00 ETo. Foram avaliados componentes de qualidade das mudas como altura, comprimento de raiz, diâmetro de colo, massa seca de raiz e parte aérea. $\mathrm{O}$ uso do hidrogel foi um diferencial para produção de mudas de tomate mais precoces, com maior altura final, maior diâmetro de colo, maior acúmulo de massa seca de parte aérea, maior área de projeção da copa e maior a taxa de crescimento relativo de parte aérea. $\mathrm{Na}$ presença do hidrogel o manejo 0.50 ETo favoreceu maiores plantas, com colo mais fino e menor massa seca de parte aérea.

PALAVRAS-CHAVE: Eficiência do uso da água. Produção de hortaliças. Recursos hídricos. 


\section{REFERENCES}

ALLEN, R. G., PEREIRA, L. S., RAES, D., SMITH, M., 1998. Crop evapotranspiration: guidelines for computing crop water requirements. In: FAO Irrigation and Drainage Paper No. 56. FAO, Rome, Italy, 300 pp.

BERNARDI, M. R.; SPEROTTO JÚNIOR, M.; DANIEL, O.; VITORINO, A. C. T. Crescimento de mudas de Corymbia citriodora em função do uso de hidrogel e adubação. Cerne v. 18, n. 1, p. 67-74, 2012. https://doi.org/10.1590/S0104-77602012000100009

BERNARDO; SOARES; MANTOVANI, E.C., DA SILVA, D.D., SOARES, A.A. Manual de Irrigação. 9. ed., 2019. COSTA, E.; LEAL, P. A. M.; BENETTI, C. G. S.; BENETT, K. S. S.; SALAMENE, L. C. P. Production of Tomato Seedlings Using Different Substrates and trays in three protected environments. Engenharia Agrícola, v. 32, n. 5, p. 822-830, 2012. https://doi.org/10.1590/S0100-69162012000500002

FAGUNDES, M. C. P.; CRUZ, M. C. M., CARVALHO, R. P.; OLIVEIRA, J., SOARES, B. C. Polímero hidroabsorvente na redução de nutrientes lixiviados durante a produção de mudas de maracujazeiro-amarelo. Revista Caatinga v. 28, n. 1, p. 121-129, 2015.

HERNÁNDEZ, H. H.; BENAVIDES-MENDOZA, A.; ORTEGA-ORTIZ, H.; HERNÁNDEZ-FUENTES; A. D.; JUÁREZ-MALDONADO, A. Cu Nanoparticles in chitosan-PVA hydrogels as promoters of growth, productivity and fruit quality in tomato. Emirates Journal of Food and Agriculture v. 29, n. 8, p. 573-580, 2017.

LINO, D. R.; LIMA NETO, B. P.; QUEIROZ, L. L.; FEITOSA, P. B.; RODRIGUES, A. A.; TEIXEIRA, A. S. Irrigação automatizada com plataforma de desenvolvimento arduino na horta didática da Universidade Federal do Ceará. Irriga, v.1, n.1, p.85-93, 2017. https://doi.org/10.15809/irriga.2017v1n1p85-93

MARQUES, P. A. A.; CRIPA, M. A. M.; MARTINEZ, E. H. Hidrogel como substituto da irrigação complementar em viveiro telado de mudas de cafeeiro. Ciência Rural, v.43, n.1, p.1-7 , 2013. https://doi.org/10.1590/S0103-84782012005000129

NAVROSKI, M. C.; ARAÚJO, M. M.; CUNHA, F. S.; BERGHETTI, A. L. P.; PEREIRA, M. O. Redução da adubação e melhoria das características do substrato com o uso do hidrogel na produção de mudas de eucalipto. Ciência Florestal v. 26, n. 4, p. 1155, 2016. https://doi.org/10.5902/1980509825106

REGHIN, M. Y.; OTTO, R. F.; OLINIK, J. R.; JACOBY, C. F. S. Viabilidade do sistema de produção de mudas em bandejas em três cultivares de cebola. Ciência e Agrotecnologia v. 31, n. 4, p. 1075-1084, 2007. https://doi.org/10.1590/S1413-70542007000400020

SANTOS, H. T.; CARVALHO, D. F.; SOUZA, C.; MEDICI, L. Cultivo de alface em solos com hidrogel utilizando irrigação automatizada. Revista Engenharia Agrícola v. 35, n. 5, p. 852-862, 2015.

https://doi.org/10.1590/1809-4430-Eng.Agric.v35n5p852-862/2015

STEIDLE NETO, A. J.; ZOLNIER, S.; LOPES, D. C. Development and evaluation of an automated system for fertigation control in soilless tomato production. Computers and Electronics in Agriculture v. 103, p. 17-25, 2014. https://doi.org/10.1016/j.compag.2014.02.001

TITTONELL, P. A.; DE GRAZIA, J.; CHIESA, A. Adición de polímeros superabsorbentes en el medio de crecimiento para la producción de plantines de pimiento. Horticultura Brasileira v. 20, p. 641-645, 2002. https://doi.org/10.1590/S0102-05362002000400026

VALNIR JUNIOR, M.; RIBEIRO, F. C.; ROCHA, J. P. A.; LIMA, R. V.; CARVALHO, C. M.; GOMES FILHO, R. R. Desenvolvimento de um software para o manejo da microirrigação. Revista Brasileira de Agricultura Irrigada, v.11, n.2, p. 1324 - 1330, 2017. https://doi.org/10.7127/rbai.v11n200616

WALTHIER, M.; SILVA, M. A. S.; SCHWENGBER, J. E.; FONSECA, F. D.; NORMBERG. Produção de mudas e cultivo a campo de beterraba em sistema orgânico de produção. Revista Brasileira de Agropecuária Sustentável , v.6, n.2, p.51-57, 2016. https://doi.org/10.21206/rbas.v6i2.328 